\title{
The Effect of Work Culture and Organizational Commitments to Performance of Employees Factory of Pt Semen Baturaja (Persero) Tbk
}

\author{
Gili Aprial Braja, Badia Perizade, Dan Zunaidah
}

\begin{abstract}
: this research aims to analyzes the influence of work culture and organizational commitment on the performance of PT. Semen Baturaja (Persero) Tbk. The analysis technique used is multiple linear regression analysis with a sample of 181 employees of PT. Semen Baturaja (Persero) Tbk. The results of the study can be concluded that the independent variables namely work culture and organizational commitment can influence employee performance significantly in PT. Semen Baturaja (Persero) Tbk.
\end{abstract}

Keywords: Work Culture, Organizational Commitment, Employee Performance, PT. Semen Baturaja (Persero) Tbk

\section{I.INTRODUCTION}

The development of the business world in the current era of globalization has triggered increasingly fierce business competition among companies. Various kinds of innovations / breakthroughs in the fields of science, technology and information systems were created by each company to be able to produce products or services that are in accordance with the needs of consumers and able to compete in the global market. In the cement industry, several cement producers in the Southeast Asia region have begun to make an innovation to answer consumers' desire in choosing cement products that have the best quality, are easy to use, and have competitive prices (Annual Rapport, 2017: 01). PT Semen Baturaja (Persero) Tbk is a company with the status of a State-Owned Enterprise (BUMN) in South Sumatra. In line with the company's development demands to realize its vision and mission which has become the determination of the entire management of the company and employees, the company has increased production capacity with the addition of a new factory or Baturaja II factory. With the existence of the new factory, the strategic step that must be implemented is to prepare all aspects including the readiness of Human Resources (HR) in order to provide the best for the company. The high competitiveness of companies in the era of globalization makes companies create and hold ideas, ideas, and strategies both marketing strategies, maximizing Human Resources (HR), adapting companies in new environments, product innovation, and others in almost all companies . To get good results from an idea or idea and strategies - strategies that have been made and formed, the company really needs to create and formulate an ideology as the basis for the establishment of the company.

Revised Manuscript Received on August 14, 2019.

* Correspondence Author

Gili Aprial Braja*, Magister Management Sriwijaya University, Indonesia

Badia Perizade, Magister Management Sriwijaya University, Indonesia

Dan Zunaidah, Magister Management Sriwijaya University, Indonesia

(C) The Authors. Published by Blue Eyes Intelligence Engineering and Sciences Publication (BEIESP). This is an open access article under the CC BY-NC-ND license (http://creativecommons.org/licenses/by-nc-nd/4.0/)
The ideology in question is a corporate organizational culture in which there are visions and missions as well as corporate values that are created and formulated by one individual namely the philosophy of the founder and company leader and carried out by a group of individuals in the company (ACT Consulting, 2018: 02). In the world of Human resource management, there have been many previous studies that discussed the impact of the work culture of the organization on the progress of HR. However, among the many studies there are still gaps or research gaps that have not been explained or discussed so as to enable subsequent research to be able to contribute deeply through them. The research gap is a gap that arises based on previous studies that may not have been explained and have not been discussed or touched by previous research, in other words a "problem" (Ferdinand, 2014: 02). Through a series of literature review, the authors assume that the existing work culture certainly has an influence on current employee performance. But what kind of influence, strong or maybe weak influence on employee performance has not been known until now because since the change in the culture of organizational work carried out in 2018 there has never been a survey that could answer that. Through the results of this study the authors hope to get a complete picture of the work culture as an evaluation material for the future in order to improve the performance of employees of PT Semen Baturaja (Persero) Tbk. Furthermore, in addition to organizational work culture there are other factors that can potentially affect employee performance in a large organization such as SMBR. These factors are one of them is organizational commitment. (Christina and Maren, 2010) quoted by Priantoro, 2012: 79). According to Greenberg and Baron, (2003: 160) states that organizational commitment is a level where individuals identify and engage with their organization and do not want to leave it. Meanwhile, another opinion suggests that organizational commitment is the level of loyalty felt by individuals towards the organization. (Schemerhorn, Hunt, Osborn, and Uhl - Bien, 2011: 72). Changes in work culture and organizational commitment is a study that is currently needed to evaluate every policy that has been planned and realized at PT Semen Baturaja (Persero) Tbk. Therefore, the authors are interested in conducting further research on this topic.

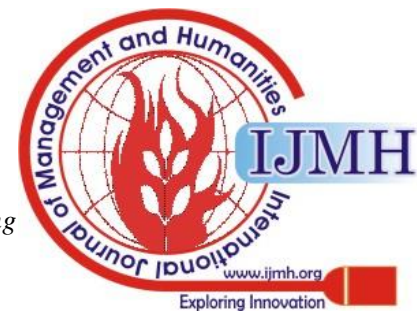


The Effect of Work Culture and Organizational Commitments to Performance of Employees Factory of Pt Semen Baturaja (Persero) Tbk

\section{II.LITERATUR REVIEW}

\section{HR Performance}

Performance is the result of a person as a whole during a certain period in carrying out tasks, such as standard results of work, targets or target criteria that have been determined in advance and have been agreed upon (Veithzal, 2005: 97). The term performance comes from Job Performance or Actual Performance which is also called the work performance achieved by employees. According to Mangkunegara (2009: 67), performance is the result of work in quality and quantity achieved by an employee in carrying out his duties in accordance with the responsibilities given to him. While Wirawan (2009: 5), explaining performance is the output produced by the functions or indicators of a job or a profession in a certain time.

\section{Organizational Work Culture}

Work culture is an organization of broad commitment in efforts to build human resources, work processes and better work results. To achieve a better level of quality, it is expected to come from the behavior of each individual involved in the work organization itself. Each function or work process has different ways of working, which results in different values that are suitable to be taken within the organizational framework.

\section{Organizational Commitment}

The concept of organizational commitment is related to the level of involvement of people with organizations where they work and are interested in staying in the organization. Experts' opinions about commitment vary greatly according to their individual perspectives.

Organizational commitment is a condition where an employee sided with a particular organization and its goals and desires to maintain membership in the organization. So high job involvement means taking sides with certain work of an individual, while high organizational commitment means taking sides with the organization that recruits the individual (Robbins, 2008: 53).

\section{III.RESEARCH METHODOLOGY}

The data used are qualitative and quantitative data from the results of the questionnaire. The resources used are data collected by researchers by distributing questionnaires to a number of employees of PT. Semen Baturaja (Persero) Tbk. The variables used in this study are Work Culture and Organizational Commitment as independent variables and Employee Performance as the dependent variable.

The population in this research is all BTA I \& BTA II factory employees of PT. Semen Baturaja (Persero) Tbk totaling 331 people. As for the sample based on Slovin calculations as many as 181 BTA I \& BTA II factory employees PT. Semen Baturaja (Persero) Tbk.

The data analysis technique used is multiple linear regression analysis by testing the correlation coefficient, the coefficient of determination, the Variable Partial Test ( $t$ test) and the suitability test of the research model (test f).

\section{IV.RESULTS AND DISCUSSION}

\section{Analysis of Multiple Linear Regression}

Multiple linear regression analysis techniques are used to see how the independent variables influence the dependent variable. In this study, the variables of Work Culture (X1) and Organizational Commitment (X2), on the performance of SMBR (Y) Employees. The following shows the results of SPSS data processing for multiple linear regression equations:

Table 1. Coefficients ${ }^{\mathrm{a}}$

\begin{tabular}{|c|c|c|c|c|c|}
\hline \multicolumn{6}{|c|}{ Coefficients $^{\mathbf{a}}$} \\
\hline \multirow[b]{2}{*}{ Model } & \multicolumn{2}{|c|}{$\begin{array}{l}\text { Unstandardized } \\
\text { Coefficients }\end{array}$} & \multirow{2}{*}{$\begin{array}{c}\text { Standardized } \\
\text { Coefficients } \\
\text { Beta } \\
\end{array}$} & \multirow[t]{2}{*}{$\mathrm{t}$} & \multirow[t]{2}{*}{ Sig. } \\
\hline & B & Std. Error & & & \\
\hline $1 \quad$ (Constant) & .171 & .128 & & 1.330 & .185 \\
\hline BDK_SMBR & .271 & .066 & .228 & 4.133 & .000 \\
\hline Commitment_SMBR & .689 & .053 & .719 & 13.051 & .000 \\
\hline
\end{tabular}

a. Dependent Variable: The Performance_SMBR

Source: Primary Data Processed with SPSS Version 23

Based on the results of the data processing, the regression equation is formulated as follows:

$$
\mathrm{Y}=0.171+0.271 \mathrm{X} 1+0.689 \mathrm{X} 2+\mathrm{e}
$$

This equation can be summarized as follows:

a) 0.171 is a constant value, which means that the performance of current SMBR (Y) employees is 0.171 units, assuming that the work culture variable (X1) and organizational commitment variable (X2) are currently constant / constant

b) Work culture regression coefficient (X1) is 0.271 , This result provides evidence that the performance of
SMBR factory employees will directly increase by 0.271 if the work culture variable (X1) is increased by 1 Unit.

c) Regression coefficient value of organizational commitment (X2) of 0.689 , This result provides evidence that the performance of SMBR factory employees will directly increase by 0.689 if the organizational commitment variable (X2) is increased by 1 Unit.

Published By:

Blue Eyes Intelligence Engineering \& Sciences Publication 
So from the results above it can be concluded that from the two independent variables studied, the largest coefficient value is the variable organizational commitment. This means that organizational commitment variables are more dominant influence on the performance of SMBR factory employees.

\section{Analysis of Correlation Coefficient (r) and Determination Coefficient $\left(\mathbf{R}^{2}\right)$}

Correlation coefficients (r) are used to see the closeness relationship between the independent variable and the dependent variable. While the coefficient of determination $\left(\mathrm{R}^{2}\right)$ to see the extent to which the ability of individual models is able to explain the dependent variable.

The following shows the results of SPSS data processing regarding the results of the correlation analysis (r) and the coefficient of determination $\left(\mathrm{R}^{2}\right)$ between the Independent variables $(\mathrm{X})$ and the dependent variable $(\mathrm{Y})$ :

Tabel 2. Model Summary

\begin{tabular}{ccccc}
\hline \multicolumn{4}{c}{ Model Summary $^{\mathbf{b}}$} \\
\hline Model & $\mathrm{R}$ & $\mathrm{R}$ Square & $\begin{array}{c}\text { Adjusted R } \\
\text { Square }\end{array}$ & $\begin{array}{c}\text { Std. Error of the } \\
\text { Estimate }\end{array}$ \\
\hline 1 &, $919^{\mathrm{a}}$ & .844 & .842 & .27571 \\
\hline
\end{tabular}

a. Predictors: (Constant), KOMITMEN_SMBR, BDK_SMBR

b. Dependent Variable: KINERJA_SMBR

Source: Primary Data Processed with SPSS Version 23

From table two above, it can be seen that the correlation coefficient (r) at number 0.919 ranges between intervals (0.80-1.00), which means that the relationship between independent variables and dependent variables is included in the very strong interval cetogy. While the coefficient of determination (R2) can be seen in the second table at 0.844 or $84.4 \%$. This means that the percentage of independent variables can affect dependent variables is 84.4 percent, and the remaining 15.6 percent is influenced by other variables outside of the research used.

\section{Partial Test (t - Partial)}

Testing $\mathrm{t}$ shows that the influence of independent variables can partially explain the dependent variable (Sanusi, 2011: 145).

The following is the result of the significance test (Test-t) used to answer the research hypothesis as follows:

Table 3. Test - t (Partial) Research Variables

\begin{tabular}{llccccc}
\hline \multicolumn{7}{c}{ Coefficients $^{\mathbf{a}}$} \\
\hline Model & Unstandardized & $\begin{array}{c}\text { Standardized } \\
\text { Coefficients } \\
\text { Coefficients } \\
\text { Beta }\end{array}$ & Std. Error & t & Sig. \\
\hline 1 & (Constant) & .171 & .128 & & $\mathbf{1 . 3 3 0}$ & $\mathbf{. 1 8 5}$ \\
& BDK_SMBR & .271 & .066 & .228 & $\mathbf{4 . 1 3 3}$ & $\mathbf{. 0 0 0}$ \\
& KOMITMEN_SMBR & .689 & .053 & .719 & $\mathbf{1 3 . 0 5 1}$ & $\mathbf{. 0 0 0}$ \\
\hline
\end{tabular}

a. Dependent Variable: KINERJA_SMBR

Source: Primary Data Processed with SPSS Version 23

Based on the results of the Test for Significance of the variable work culture $(X \neg 1)$, the significant value at $\alpha=$ 0.05 is obtained because the value of t-count is greater than t-table (4,133 greater than 1,973) or value (Sig.) 0,000 smaller than 0.05 . it can be concluded that the effect of work culture (X1) on performance $(\mathrm{Y})$ is significant. Based on the results of the $t$ test, the organizational commitment variable (X2) gets a significant value at $\alpha=0.05$ because the t-count value is greater than t-table $(13,051>1,973)$ or the value (Sig.) 0,000 is smaller than 0.05 . it can be concluded that the effect of organizational commitment (X2) on performance (Y) is significant.
Conformity Test for Research / Test Models - F (Significant)

According to Sanusi (2011: 148) in his book F Test basically shows whether all independent variables (variables $\mathrm{X} 1, \mathrm{X} 2$ ) that are included in the model have a simultaneous influence on the dependent variable (Y).

The following is the result of the significance test (F-Test) which is used to answer the research hypothesis as follows: 
The Effect of Work Culture and Organizational Commitments to Performance of Employees Factory of Pt Semen Baturaja (Persero) Tbk

\begin{tabular}{|c|c|c|c|c|c|c|}
\hline \multicolumn{7}{|c|}{$\frac{\text { Table 4. Anova }^{\mathrm{a}}}{\text { ANOVA }^{\mathrm{a}}}$} \\
\hline & Model & Sum of Squares & $d f$ & Mean Square & $\mathbf{F}$ & Sig. \\
\hline & Regression & 73.202 & 2 & 36.601 & 481.478 &, $000^{\mathrm{b}}$ \\
\hline 1 & Residual & $\begin{array}{l}13.531 \\
86733\end{array}$ & $\begin{array}{l}178 \\
180\end{array}$ & .076 & & \\
\hline
\end{tabular}

a. Dependent Variable: KINERJA_SMBR

b. Predictors: (Constant), KOMITMEN_SMBR, BDK_SMBR

Source: Primary Data Processed with SPSS Version 23

From the table above, it can be seen that the F-test (Anova) results show that the calculated $\mathrm{F}$ value is $481,478>\mathrm{F}$ table is 3,050 and the level of significance simultaneously sig $\mathrm{F}$ is 0,000 . This shows that together (simultaneously) the independent variables in the study, namely work culture (X1) and organizational commitment (X2) have a significant influence on the performance dependent variable (Y).

\section{Discussion of Research Results}

This study discusses how the factors of influence interact so that they can influence the performance of HR in a company organization. HR performance is an abstract and dynamic thing. It changes continuously as changes in the organizational environment, technology, and science. Therefore it is very important for organizations to always evaluate in response to this so that at any time and at any time the organizational policies intended for $\mathrm{HR}$ can be prepared and adjusted well and on target and this will have an impact on the performance of HR that is stable in accordance with what expected in the implementation. Based on the results of the analysis on 4 indicators of work culture, it can be seen that the average score in the work culture variable shows the number 3.59 in the interval 4 in the high category. This means that the application of the work culture that exists at the Baturaja Cement plant is considered to be quite good. However, stability can be maintained and may be even better if it can be improved so that it can encourage employee performance so that they can be more productive in situations of changing business conditions (Dynamic). This is consistent with Buchanan, Huczyski, and Koesmono's opinions. (2005: 75); which states that culture has full strength, which can affect individuals and their performance even in the work environment of the organization. Based on the results of the respondents' statement recapitulation on organizational commitment variables, it can be seen that the average score figures show 3.54 for all indicators. organizational commitment of employees of PT Semen Baturaja (Persero) Tbk factory are in the high category or interval value 4 . This can be concluded that employees of PT Semen Baturaja (Persero) Tbk Factory have the potential to have a high level of work involvement (loyalty) towards the company.

According to Wibowo (2015: 187), the success of an organization can also be seen from the success of management in fostering the organizational commitment of employees in it. Without organizational commitment, it is very difficult to expect active and deep participation from employees. Therefore, organizational commitment must be maintained in order to continue to grow and exist in the employee's heart as the most important asset in an organization such as PT Semen Baturaja (Persero) Tbk. This can be concluded even though the employee's performance is good but there are still a few shortcomings in teamwork. In line with these findings, If employee performance wants to be improved, in addition to choosing alternative policies that already exist. Management of PT. Semen Baturaja (Persero) can also initiate through alternative policies on efforts to strengthen teamwork in the work environment of PT Semen Baturaja (Persero) Tbk's factory employees. Management can maximize teamwork to encourage employee performance to be more productive in the future. (Optional).

\section{V.CONCLUSION}

Based on the analysis and discussion, conclusions can be drawn as follows:

1) Work Culture Variable (X1) Organizational Commitment (X2) has a positive and significant effect both partially and simultaneously on the performance of PT Semen Baturaja (Persero) Tbk's factory employees.

2) Variable Organizational Commitment (X2) is an independent variable whose influence is more dominant on the performance of PT Semen Baturaja (Persero) Tbk. Factory employees.

\section{SUGGESTION}

Based on the results of the analysis and discussion in this study, suggestions can be put forward as follows:

1) For the management of PT Semen Baturaja (Persero) Tbk:

In this study the existing work culture is considered to be good enough, but among them there are still gaps especially in indicator 2 regarding team work, namely the ability to be able to work together in achieving common goals. This shows that the application of work culture to this indicator still needs to be improved. Because basically team collaboration is a determinant of the strength of the organization itself. For this reason, the writer recommends SMBR management to be able to make a policy oriented to efforts to strengthen work team collaboration such as through 
HR training, social activities between employees, Rotation and promotion so as to maximize the involvement of every existing element of workers in the PT Semen Baturaja (Persero) Tbk factory, so that in the future more solid teamwork can be formed from before.

a) Based on the results of recapitulation of respondents statements on variable organizational commitment it can be concluded that employees of PT Semen Baturaja (Persero) Tbk's factory have a high commitment to the company. But if observed more specifically the level of satisfaction in completing employee work is still somewhat lower than other indicators of organizational commitment. This needs to be a concern for Semen Baturaja management to better understand the employee's aspirations about what is important to them in their work what is expected by employees for the future and the continuity of their work. Especially employees who are in the PT Semen Baturaja (Persero) Tbk factory that are very susceptible to experiencing saturation of the situation and conditions in the Semen Baturaja factory.

2) For the next researcher, it is expected that the results of this study can be a reference material or further research literature related to work culture, organizational commitment, and the performance of company employees as well as information material or studies in the field of Human Resource Management. It is also expected that in future studies to be able to add other variables that have not been predicted in this study such as, Job stress, Employee Ability, HR Training, Leadership and so forth. Which of course can strengthen the influence on the performance of SMBR factory employees and with more in-depth studies based on theories that may not have been used in this study.

\section{REFERENCES}

1. ACT Consulting. (2018). Workshop Report MVVM Workshop (Mission, Vision, Values \& Meaning) PT SEMEN BATURAJA (PERSERO) TBK.

2. Annual Rapport. (2017). Perubahan Sruktur Organisasi Departemen Operasi (Existing) Dan Pabrik Baturaja II PT SEMEN BATURAJA (PERSERO) TBK. http://www.mulawarmaninstitute.net/wpcontent/uploads/2018/06/Rancangan-Struktur-Organisasi-PT.-SemenBaturaja-Persero-Tbk-2017..pdf.

3. Anwar Prabu Mangkunegara. (2009). Evaluasi Kinerja Sumber Daya Manusia. Bandung: Penerbit Refika Aditama.

4. Christina \& Maren, S. (2010). Exporting Service Sucssesfully : Antedecents and Performance Implications of Customer Relationships. Journal of International Marketing.

5. Colquitt, Jason A., Jeffery A. LePine, and Michael J. Wesson. (2011) Organizational Behavior. New York: McGraw-Hill.

6. Ghozali, Imam. (2013). Aplikasi Analisis Multivariate dengan Program IBM SPSS. Semarang: Badan Penerbit Universitas Diponegoro.

7. Gibson, James L., Donnelly Jr, James H., Ivancevich, John M., Konopaske, Robert (2012). Organizationa Behavior, Structure, Processes, Fourteenth Edition (International Edition).1221 Avenue of The Americas, New York, NY 10020: McGraw-Hill.

8. Gipson, James L, John M Ivancevich dan James H. Jr Donnely (2010). Organisasi dan Manajemen. Edisi terjemahan. Jakarta : Erlangga.

9. Gomez, Faustino Cardodo. 2003. Manajemen Sumber Daya Manusia Yogyakarta : Andi Offset.

10. Greenberg, Jerald dan Robert Baron (2003). Behavior in Organizations ( understanding and managing the human side of work ). Eight edition, Prentice Hall.

11. Heriyanti, Dewita. (2007). "Analisis Pengaruh Budaya Organisasi, Kepuasan Kerja, dan Gaya Kepemimpinan terhadap Kinerja
Karyawan dengan Komitmen Organisasional sebagai Variabe Interving Pada PT. PLN APJ Semarang". Skripsi. Semarang: Universitas Diponegoro.

12. https://ppm-manajemen.ac.id/event/manajemen-sumber-dayamanusia-2018-11-05-2018-12-14-4073/register. diakses : 09/10, (2018).

13. Ivancevich, John M. (2010). Human Resource Management. International Edition. 1221 Avenue of The Americas, New York: Mc Graw Hill.

14. Koesmono, T. (2005), Pengaruh Budaya Organisasi Terhadap Motivasi dan Kepuasan Kerja Serta Kinerja Karyawan Pada Sub Sektor Industri Pengolahan Kayu Skala Menengah Di Jawa Timur, Jurnal Manajemen dan Wirausaha Vol. 7. No. 2 September 2005.

15. Luthans, Fred. (2011). Organizational Behavior : An Evidence-Based Approach. New York: McGraw-Hill.

16. Mathis, R.L. \& J.H. Jackson. (2006). Human Resource Management: Manajemen Sumber Daya Manusia. Terjemahan Dian Angelia. Jakarta: Salemba Empat.

17. McShane, Steven L., and Mary Ann Von Glinow, (2000), Organizational Behavior,. McGraw-Hill Companies ...

18. Meliawati, V., Sunaryo, H., (2018) Pengaruh Kompensasi, Motivasi, Dan Komitmen Organisasional Terhadap Kinerja Karyawan Giant Ekstra Gajayana Malang. e - Jurnal Riset Manajemen Prodi Manajemen Fakultas Ekonomi Unisma.

19. Miner, John. (1998). Organizational Behavior, Performance and Productivity. New.

20. Ndraha, Taliziduhu. (2003). Kybernologi (Ilmu Pemerintahan Baru). Jilid 1-2. Rineka Cipta. Jakarta.

21. Ndraha, Taliziduhu. (2003). Kybernologi (Ilmu Pemerintahan Baru) Jilid 1-2. Rineka Cipta. Jakarta.

22. Newstrom, J.W. (2011). Organizational Behavior Human Behavior at Work (13th ed) New York : McGraw-Hill

23. Notoatmodjo, Soekidjo. (2009). Pengembangan Sumber Daya Manusia. Jakarta: Rineka Cipta.

24. Osborn dan Plastrik. (2002). Manajemen Sumber Daya Manusia. Yogyakarta.

25. Putriana, HM., Herawati, J., (2018) Pengaruh Kemampuan Kerja, Kepuasan Kerja Dan Komitmen Organisasi Terhadap Kinerja Karyawan PD. BPR BKK Kebumen. Universitas Sarjanawiyata Tamansiswa.

26. Rahadi, Dedi Rianto. (2010). Manajemen Kinerja Sumber Daya Manusia. Malang: Tunggal Mandiri Publishing

27. Rahadi, Dedi Rianto. (2010). Manajemen Kinerja Sumber Daya Manusia. Malang : Tunggal Mandiri Publishing

28. Robbins, Stephen P. \& A. Judge, Timothy (2011). Organizational behavior. Fourteenth Edition. Pearson education. New Jersey 07458. 77-89.

29. Schermerhorn, J. R., Hunt, J. G., Osborn, R. N., dan Uhl-Bien, M (2010). Organizational Behavior 11th Edition. New Jersey: John Wiley \& Sons, Inc.

30. Simamora, Henry. (2004). Manajemen Sumber Daya Manusia. Yogyakarta: STIE YKPN.

31. Simamora, Henry. (2006). Manajemen Sumber Daya Manusia Yogyakarta: STIE YKPN

32. Simanjuntak, Payaman J. (2005). Manajemen dan Evaluasi Kinerja. Jakarta: FE UI.

33. Sopiah. 2008. Perilaku Organisasi, Andi, Yogyakarta

34. Swari, R,C., Firdaus, Y. (2018). Mengenal Gangguan Psikosomatis, Saat Pikiran Memengaruhi Kesehatan Tubuh. https://hellosehat.com/hidup-sehat/fakta-unik/apa-itu-gangguanpsikosomatis/. Di akses 26 January 2019.
Published By:

Blue Eyes Intelligence Engineering \& Sciences Publication (C) Copyright: All rights reserved. 